NOW WE ARE CITIZENS 



\section{Now We Are Citizens}

INDIGENOUS POLITICS IN

POSTMULTICULTURAL BOLIVIA

Nancy Grey Postero

STANFORD UNIVERSITY PRESS

STANFORD, CALIFORNIA 


\section{Stanford University Press}

Stanford, California

(C) 2007 by the Board of Trustees of the Leland Stanford Junior University. All rights reserved.

No part of this book may be reproduced or transmitted in any form or by any means, electronic or mechanical, including photocopying and recording, or in any information storage or retrieval system, without the prior written permission of Stanford University Press.

Library of Congress Cataloging-in-Publication Data Postero, Nancy Grey.

Now we are citizens : indigenous politics in postmulticultural Bolivia / Nancy Grey Postero.

p. $\mathrm{cm}$.

Includes bibliographical references and index.

ISBN-I 3: 978-0-8047-55 I9-I (cloth : alk. paper)

ISBN-I 3: 978-0-8047-5520-7 (pbk. : alk. paper)

I. Guarani Indians-Bolivia-Santa Cruz (Dept.)-Politics and govern-

ment. 2. Guarani Indians-Bolivia-Santa Cruz (Dept.)-Government

relations. 3. Multiculturalism-Political aspects-Bolivia-Santa Cruz

(Dept.) 4. Santa Cruz (Bolivia : Dept.)-Ethnic relations-Political aspects.

5. Santa Cruz (Bolivia : Dept.)-Politics and government. I. Title.

\section{F2230.2.G72P67 2007}

323 . II98' $38220843-\mathrm{dc} 22$

2006017975

Typeset by BookMatters in Io/I2.5 Sabon

Original Printing 2006

Last figure below indicates year of this printing:

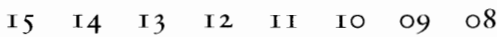


For Cissie 
